\title{
Vendor Satisfaction of E-government Procurement Systems in Developing Countries An Empirical Research in Indonesia
}

Seo, Dongback; Tan, Chee-Wee; Warman, Gumala

\author{
Document Version \\ Accepted author manuscript \\ Published in: \\ Information Technology for Development
}

DOI:

10.1080/02681102.2018.1454878

Publication date:

2018

License

Unspecified

Citation for published version (APA):

Seo, D., Tan, C-W., \& Warman, G. (2018). Vendor Satisfaction of E-government Procurement Systems in Developing Countries: An Empirical Research in Indonesia. Information Technology for Development, 24(3), 554-581. https://doi.org/10.1080/02681102.2018.1454878

Link to publication in CBS Research Portal

\section{General rights}

Copyright and moral rights for the publications made accessible in the public portal are retained by the authors and/or other copyright owners and it is a condition of accessing publications that users recognise and abide by the legal requirements associated with these rights.

\section{Take down policy}

If you believe that this document breaches copyright please contact us (research.lib@cbs.dk) providing details, and we will remove access to the work immediately and investigate your claim.

Download date: 26. Apr. 2023



\title{
Vendor Satisfaction of E-government Procurement Systems in Developing Countries: An Empirical Research in Indonesia
}

\author{
Dongback Seo, Chee-Wee Tan, and Gumala Warman \\ Journal article (Accepted manuscript*)
}

\section{Please cite this article as:}

Seo, D., Tan, C-W., \& Warman, G. (2018). Vendor Satisfaction of E-government Procurement Systems in Developing Countries: An Empirical Research in Indonesia. Information Technology for Development, 24(3), 554-581. https://doi.org/10.1080/02681102.2018.1454878

This is an Accepted Manuscript of an article published by Taylor \& Francis in Information Technology for Development on 25 Mar २०18, available online:

DOl: http://www.tandfonline.com/10.1080/02681102.2018.1454878

* This version of the article has been accepted for publication and undergone full peer review but has not been through the copyediting, typesetting, pagination and proofreading process, which may lead to differences between this version and the publisher's final version AKA Version of Record. 


\title{
Vendor Satisfaction of E-government Procurement Systems in Developing Counties: An Empirical Research in Indonesia
}

\author{
Dongback Seo \\ Department of Management Information Systems \\ Chungbuk National University \\ Cheongju, Chungbuk, Republic of Korea \\ dseo@ chungbuk.ac.kr \\ Chee-Wee Tan \\ Department of Digitization \\ Copenhagen Business School \\ Copenhagen, Denmark \\ ct.digi@cbs.dk \\ Gumala Warman \\ Ministry of Communication and Information Technology \\ Jakarta, Indonesia
}

Paper Accepted at Information Technology for Development (ITD).

Please do not quote or cite without permission. Comments are welcome.

Please address all correspondence to the first author. 


\title{
Vendor Satisfaction of E-government Procurement Systems in Developing Counties: An Empirical Research in Indonesia
}

\begin{abstract}
Adoption of e-government services persists as a prime concern among scholars and practitioners. Although much progress has been attained in comprehending how e-government services have been adopted by citizens, our understanding of vendors' willingness to engage in Government-to-Business transactions (e.g., $e$ procurement) is much more limited by comparison, especially from the perspectives of service convenience and performance failure. For this reason, there have been increasingly calls for further investigations into the factors affecting vendors' adoption of e-government services and especially those operating in developing countries. Drawing on the compatibility principle, we advance a theoretical model that posits performance failure of e-government systems as object-based beliefs affecting vendors' behavioral-based belief of service convenience. Upon analyzing survey data gathered from 227 vendors based in Indonesia on their experiences with e-government procurement systems, we discover that vendors' evaluations of service convenience are negatively influenced by the presence of information, function and system failures and that the effects of these failures vary across different dimensions of service convenience. In turn, service convenience and performance failure exert opposite impact on vendors' satisfaction with e-government systems.
\end{abstract}

Keywords: e-government, e-procurement, service convenience, information failure, function failure, and system failure 


\section{Introduction}

The mass migration of public services onto digital media has led to an emerging genre of e-government systems that rely on IT-enabled web interfaces as the focal point of contact between governmental institutions and stakeholders (Siau and Long, 2009; Tan and Pan, 2003). A report released by Accenture (2009) on e-government maturity across a sample of 21 countries indicates that a majority of these countries (> 90\%) have not only digitized at least $80 \%$ of their public services, there is also evidence of increasing sophistication in the delivery of such eservices to cater to citizens' individual requirements. Yet, despite the rapid growth of egovernments worldwide, much of this progress is concentrated in developed countries. As concluded in a United Nations e-government readiness survey conducted in 2008, e-government adoption in developing countries is lagging behind developed countries due to the former's inability to realize public e-service initiatives (United Nations, 2008). For this reason, a handful of scholars have questioned whether lessons learnt from past studies of e-government systems in predominantly developed countries are applicable to developing countries (e.g., Chen et al., 2006). Specifically, Dada (2006) has appealed for further research into factors affecting egovernment diffusion in developing countries.

Electronic procurement (or e-procurement) is one of the most widely utilized e-business applications among organizations (Davila et al., 2003). An e-procurement system allows organizations to automate transactions with multiple vendors when sourcing for goods and services, leading to reduced cycle time and enhanced productivity for both parties (Gunasekaran and Ngai, 2008). The same can be said for governmental institutions. An e-procurement system facilitates governmental institutions in conducting online public tenders by extending its reach to qualified bidders and offering equal opportunities to all (Moon, 2005). A public tender refers to a 
bidding process that is open to all qualified bidders to select a supplier on the basis of price and quality. It provides flexibility to vendors in term of time, cost, and effort when participating in public tenders (Donthu and Garcia, 1999). This is especially important for vendors located in developing countries because they often face difficulties with being physically present for public tenders due to long distance and poor infrastructure. With the introduction of e-government procurement systems however, vendors can easily participate in public tenders regardless of their geographical proximity.

Another function of an e-government procurement system lies in its ability to minimize corruption related to governmental procurement. Procurement often culminates in corruption and the abuse of public resources within developing countries (Liao et al., 2002). Public officials in charge of awarding procurement contracts often succumb to bribery from potential vendors, especially when governmental institutions do not practice a transparent procurement process (Mahmood, 2010). In extreme situations, Mahmood (2010) remarked that "when private businesses join together to make deals with public officials for procurement contracts, concessions and privatization then an honest judiciary become helpless in front of corrupted administration" (p. 105). By rendering the entire procurement procedure transparent to participating vendors, an e-government procurement system can prevent or, at the very least, minimize corrupted practices related to governmental procurement (Mahmood 2010). With egovernment procurement systems, governmental institutions can broadcast public tender announcements to interested vendors together with predefined evaluation criteria. Vendors then submit their bids through the e-government procurement systems. These bids are electronically stored in databases and can be tracked by all participating vendors. The most qualified vendor is 
then selected based on the bids. In this sense, the accessibility and traceability of e-government procurement systems ensures that public tenders are transparent and winning bids are justified.

Dissolving geographical boundaries and eliminating corruption can hence be construed as core benefits of e-government procurement systems. To realize these benefits however, developing a convenient and well-performing e-government procurement system becomes instrumental in securing vendors' participations in online public tenders (Szymanski and Hise, 2000). For the aforementioned reasons, this study endeavors to shed light on how performance failure and service convenience of e-government procurement systems affect vendors' satisfaction towards such systems in developing countries.

We synthesize extant literature on service convenience and performance failure to advance a model that accounts for vendors' satisfaction with e-government procurement systems. Building on Ajzen's (1988) compatibility principle, we not only differentiate between performance failure and service convenience as object-based and behavioral-based beliefs respectively, but we also posit that both performance and service convenience are strong predictors of vendors' satisfaction with e-government procurement systems. Furthermore, consistent with the work of Wixom and Todd (2005), we postulate that service convenience, as a behavioral-based belief, is affected by the object-based belief of performance failure. Whenever failure occurs in an e-government procurement system, it negatively influences vendors' assessment of service convenience, which, when taken together, culminates in dissatisfaction with the system.

E-government procurement systems have attracted substantive attention within extant literature. Researchers have investigated the importance of stakeholder collaborations and alliances (Devadoss et al., 2003; Kumar and Peng, 2006), the impact of e-procurement (Croom 
and Jones, 2007), the relevant technical process (Liao et al., 2002; Panayiotou et al., 2004), as well as vendors' acceptance and resistance of e-government procurement systems (Wirtz et al., 2010). Nevertheless, these studies tend to rely on data from the experience of developers and/or project managers who were responsible for the implementation and deployment of e-government procurement systems. In comparison, there is a paucity of studies that examines e-government procurement systems from the perspective of vendors as actual system users. This study therefore expands our knowledge of e-government procurement systems by analyzing system satisfaction from the perspective of vendors. We surveyed 227 vendors who have participated in online public tenders operated by the Indonesian government. Results suggest that performance failure negatively affects vendors' evaluation of service convenience and thereafter, their satisfaction with e-government procurement systems. Findings from our empirical study can be harnessed by governmental institutions to design e-government procurement systems that satisfy vendors' service expectations.

The paper comprises five sections, inclusive of the introduction. In the next section, we develop our theoretical model together with testable hypotheses. Specifically, we draw on Ajzen's (1988) compatibility principle to argue for why performance failure of e-government procurement systems constitutes object-based beliefs affecting vendors' behavioral belief of service convenience and their subsequent satisfaction from utilizing such systems. The third section outlines our research methodology for validating the theoretical model. Next, we describe our data analysis technique and present the analytical findings in the fourth section. Finally, we summarize the key insights to be gleaned from our study and highlight how these insights contribute to theory and practice. 


\section{Theoretical Foundation and Hypotheses Formulation}

In this section, we present prior research related to e-government relationships (government to business) in the field of information systems (IS) and service convenience within the field of marketing. This paper focuses solely on G2B (Government to Businesses) public eservices from the vendors' perspective.

\subsection{Government-to-Business (G2B) E-Procurement: An Overview}

Many studies in e-government have centered on Government-to-Citizen (G2C) relationships, such as issues relating to a G2C initiative by a government (e.g., Chen et al., 2009; Seifert and Petersen, 2002) and citizens' receptivity toward e-government services (e.g., Lee et al., 2009; Mirchandani et al., 2008; Seo and Bernsen, 2016; Verdegem and Verleye, 2009; Wang and Liao, 2008). In comparison, there has been far less scholarly attention being paid to Government-to-Business (G2B) relationships. Particularly, prior research of G2B e-government initiatives tend to concentrate their efforts on uncovering the benefits of G2B initiatives such as increased operational efficiency through cost and time reductions (Panayiotou et al., 2004; Seifert and Petersen, 2002; Tung and Rieck, 2005). In turn, these benefits become important factors for governments when initiating G2B e-services (Obeidat and Abu-Shanab, 2010; Tung and Rieck, 2005). For the successful implementation of G2B systems, critical success factors such as governmental structure and users' participations have been identified (Devadoss et al., 2003; Kumar and Peng, 2006). In addition, major obstacles such as cost, privacy, security and technical problems (e.g., accessibility and usability) are recognized (DeBenedictis et al., 2002). Yet, these studies tend to investigate e-government from the viewpoint of governmental institutions without paying heed to the requirements of participating organizations. Without the participation of organizations, G2B systems are rendered meaningless. Consequently, researchers 
have appealed for greater focus on how organizations evaluate G2B e-services (e.g., Awan, 2007; Gotoh, 2008). For instance, organizations who have doubts about security do not engage in transactions even though they visit G2B websites (Awan, 2007). Likewise, organizations' evaluation of service quality in the likes of informational content and site navigability also influences their satisfaction with G2B systems (cf. Tan et al., 2013). In this sense, organizations' satisfaction with G2B systems is vital for the latter's diffusion.

Within G2B systems, e-government procurement systems are predominant applications (Alsaghier et al., 2009) because such systems can improve the transparency of procurement procedures and minimize corruption (Liao et al., 2002). Like most G2B studies, prior research on e-government procurement systems (e.g. Croom and Jones, 2007; Panayiotou et al., 2004) has attempted to identify critical success factors behind these systems such as simplified process, management commitment, interoperability with current communication systems, and internal service in delivering a system. Again, these studies are founded on the viewpoint of governmental institutions during the planning and implementation stages of an e-government procurement system. Because public procurement is important in a national economy, the transparency of procurement procedures is expected, especially for developing countries. Under these circumstances, e-government procurement systems play a significant role in ensuring procedural transparency and reaching out to organizations (or vendors) that are constrained geographically. The fate of an e-government procurement system thus relies on vendors' willingness to utilize the system. Consequently, it is imperative for us to investigate egovernment procurement systems from the perspective of vendors because they are the ones who will eventually participate in public tenders if they perceive such systems to be stable and convenient. To this end, this study draws on Ajzen's (1988) compatibility principle to 
hypothesize how vendors' experiences with performance failure and service convenience of egovernment procurement systems affects their satisfaction toward the system.

\subsection{Object-Based and Behavioral-Based Beliefs}

According to Ajzen and Fishbein's (1980) expectancy-value theory, external variables influence beliefs regarding the consequences associated with the performance of a targeted behavior, which in turn shapes attitudes towards performing the behavior. Attitude then influences intention to perform the behavior and ultimately the behavior itself (Ajzen and Fishbein, 1980). Whereas a belief references a unique attribute associated with the performance of the behavior, an attitude represents an overall evaluation of the saliency of each behavioral attribute and the strength of its association (Ajzen, 1988; Taylor and Todd, 1995), i.e. a person's attitude towards a particular behavior is equivalent to his/her assessment of each salient attribute together with its subjective probability of occurrence. Therefore, belief and attitudinal factors are predictive of behavior whenever their relationships are conceived in a manner consistent with the predicted behavior in terms of time, target and context (Fazio and Olson, 2003) - what Ajzen (1988) termed as the compatibility principle (see Fishbein and Ajzen, 1975). In other words, the compatibility principle holds that an attitude will be a better predictor of targeted behavior if the specificity at which the attitude has been conceived matches the specificity of the behavior under consideration (Ajzen \& Fishbein, 2005). This concept has been adopted in the field of management information systems, especially, studying people's perceptions and behavior of adopting and using an information technology system and information technology innovation (e.g., Seo and Bernsen, 2016).

Extrapolated to the context of this study, what is implied by the compatibility principle is that attitudes specific to the usage of e-government procurement systems can better predict the 
utilization of such systems than attitudes about e-government in general. Extending Ajzen and Fishbein's (1980) compatibility principle, Wixom and Todd (2005) hence reasoned that clear distinctions must be drawn between object- versus behavioral-based beliefs and attitudes in predicting system usage behavior. While object-based beliefs and attitudes deal with technical aspects of the system, behavioral-based beliefs and attitudes only take on meaning and purpose when targeting specific system-related behaviors (see Wixom and Todd (2005) for a comprehensive discussion). Further, by adhering to the compatibility principle (Fishbein and Ajzen, 1975), Wixom and Todd (2005) supplied empirical evidence indicating that systemrelated behaviors may be best explained by proper alignment among associated object- and behavioral-based beliefs and attitudes. In subsequent sections, we delineate performance failure into its information, function and system components, which in turn act as object-based beliefs affecting the behavioral-based beliefs of service convenience and vendors' satisfaction. We begin with an introduction of service convenience and its constituent dimensions as focal antecedents shaping vendors' satisfaction with e-government procurement systems. We then propose that performance failures are rooted in the information, function and/or system attributes of e-government procurement systems, which in turn influence vendors' perceptions of service convenience and satisfaction towards such systems. Figure 1 depicts our research model whose constructs and relationships will be elaborated in greater detail below.

\section{$<<$ Figure 1 $>>$}

\subsection{Service Convenience: An Overview}

Convenience is instrumental in satisfying and maintaining relationships with consumers who make purchases and utilize given services. Within marketing literature, the concept of convenience has been examined in relation to consumer products (e.g., Berry et al., 2002; Chang 
and Polonsky, 2012; Colwell et al., 2008). Berry et al. (2002) defined convenience goods as distributed products requiring minimal time and effort to purchase. Subsequent research further identified convenience as a key attribute (e.g., Chang et al., 2010). Scholars have increasingly come to recognize the importance of convenience in service marketing. Within the service industry, convenience is a core aspect being employed to evaluate service quality besides fairness, empathy, responsiveness and reliability (Andaleeb and Basu, 1994). Although convenience appears to share commonalities with the concept of Perceived Ease of Use (PEOU) from Technology Acceptance Model (TAM), they are distinct. Whereas PEOU measures the degree to which a user believes the usage of a system to be free from effort, service convenience reflects the extent to which the system facilitates the accomplishment of a predetermined goal (e.g., purchasing goods and services) (Tang and Chiang, 2009). In this sense, PEOU merely captures users' interaction with a system while service convenience takes into account the existence of predetermined goals in system utilization. Consumers' perceptions of service convenience will thus affect their satisfaction with services. Because response time has been conceived as a critical indicator for measuring service convenience, a decrease in consumers' waiting time translates into better customer satisfaction (Berry et al., 2002).

In the context of online services, there are a few studies that have alluded to the significance of convenience. Donthu and Garcia (1999) found that consumers are inclined to shop online because of convenience. Consumers perceive that online shopping not only increases flexibility in planning and reduces time spent, but it also conserves effort in not having to visit the store physically (Donthu and Garcia, 1999). Besides website design and security, Szymanski and Hise (2000) also identified convenience as a key determinant of consumers' desire to purchase goods online. Arguably, service convenience can be construed as a behavioral-based 
belief in that it is derived from consumers' behavior of utilizing service in practice. In the absence of usage behaviors, it is inconceivable for consumers to be able to assess the amount of time and effort required for consuming service.

Though extant literature on service convenience has largely focused on consumers' perspective in the past, we submit that it is reasonable to apply the concept in an investigation of e-government procurement systems for three reasons. First, in the context of e-government procurement systems, vendors can be regarded as consumers in that they are the actual users of these systems. Just as e-businesses strive to provide convenience to consumers who utilize their websites for performing online transactions, governments are equally motivated to roll out convenient e-procurement systems that entice vendors to participate in public tenders. Second, one can argue that governments, as service monopolies (Lim et al., 2007; Tan et al., 2005), are able to dictate procurement procedures by moving tenders online. This is usually the case for many developed countries that boast of high broadband penetration and the availability of a welleducated workforce. Nevertheless, the same cannot be said for developing countries. In developing countries, the success of e-government initiatives is predicated on the existence of adequate digital infrastructures and the educational level of their populace. For this reason, governments in developing countries place huge emphasis on simplifying their systems to make them convenient for less-educated users. Third, governments, as public entities, are obliged to offer equal opportunity to all participating vendors. Yet, not all vendors possess identical capabilities and resources. Governments must therefore act in public interest by delivering convenient e-government procurement systems to accommodate each and every vendor. For the above reasons, we subscribe to service convenience as a focal behavioral-based belief directing vendors' adoption of e-government procurement systems: 
Hypothesis 1: Service convenience of an e-government procurement system positively affects vendors' satisfaction with the system.

\subsection{Dimensions of Service Convenience on E-Government Procurement System}

Service convenience is a multi-dimensional concept. Seiders et al. (2007) developed and validated a multi-dimensional scale for service convenience from consumers' perspective. By delineating consumers' service experience into stages, Seiders et al. (2007) construed service convenience as a second-order, formative construct comprising five independent first-order constructs (or dimensions), namely access convenience, decision convenience, transaction convenience, benefit convenience, and post-benefit convenience.

Access Convenience: Consumers view time and effort as costs whenever they have to take action for services (Berry et al., 2002). Service delivery capacity such as physical location, online availability and operating hours determine the convenience of accessing services at a time of users' specification. For online transactions, access is associated with the availability of devices (e.g., computer and laptop) and Internet connections (e.g., broadband and wireless network). In the context of e-government procurement systems, governmental institutions must present multiple services through its portal such that vendors can readily gain access to these services. The availability, capability, and capacity of information systems (e.g. skills, hardware, network, and software) are related to the accessibility and participation of users (Seifert and Petersen, 2002). Therefore, ease of access and speedy delivery will reduce the time and effort expended by users for accessing services (Verdegem and Verleye, 2009). The better the access convenience is, the more positive it will be for vendors' perception of the convenience of egovernment procurement services.

Decision Convenience: Consumers devote time and effort when making decision to purchase or utilize services (Berry et al., 2002). In e-government procurement systems, vendors 
expend time and effort when deciding how they utilize services. The availability and quality of information about services influence decision convenience before users start to experience the services (Seiders et al., 2007; Tan and Benbasat, 2009). The more precise the instructions are for an e-government procurement system, the more convenient the decision-making process will be for vendors. Within marketing literature, decision convenience has been shown to positively influence consumers' service evaluations (Berry et al., 2002; Seiders et al., 2007).

Transaction Convenience: Consumers spend time and effort when they conduct and finalize transactions (Berry et al., 2002). Online transactional activities include ordering services, completing data entry as well as authentication and payment, to name a few. In the context of egovernment, transactions take place when a two-way communication is established between governmental institution and either citizens or organizations (Layne and Lee, 2001). Typically, a citizen or an organization interacts with a governmental institution through its e-government website (e.g., downloading, filling out, and uploading forms) and the governmental institution responds to the citizen or organization accordingly (e.g., uploading announcements, approving requests, as well as providing confirmations and receipts). For e-government procurement, vendors have to execute multiple transactions when supplying goods or services to governmental institutions. Because vendors are expected to adhere to stipulated procedures in accordance with governmental institutions' announcements about the tender process and requirements (e.g., downloading and filling out electronic forms), long waiting time, and extensive effort experienced by vendors will lead to transaction inconvenience.

Benefit Convenience: Consumers perceive time and effort as costs when experiencing the benefits of services. For instance, home shoppers tend to purchase books electronically due to the benefits of online shopping. These benefits include the ability to search, order, pay, and acquire 
books easily via an online store without ever having to leave their homes. In term of egovernment procurement services, vendors tend to utilize services in order to participate in public tenders. Both governments and vendors have recognized the benefits of e-procurement services (Panayiotou et al., 2004; Tung and Rieck, 2005). Consequently, e-government procurement systems should be designed in ways that allow vendors to realize the benefits of efficiency and transparency from utilizing such systems.

Post-Benefit Convenience: Post-benefit convenience refers to the time and effort that consumers spend on service maintenances, exchanges, or failure recoveries after utilizing services. In the e-government procurement context, vendors tend to reinitiate contact with a governmental institution for the purpose of tracking transactions, resolving transactional problems, or complaining about failures if they occur. Possible problems include issues related to helpdesk service, payment, and security (Holloway and Beatty, 2003). Service failures often assume the form of vendors' complaints in the post-benefit phase. In this phase, recovery measures must be undertaken by a governmental institution in order to handle vendors' reactions to these service failures. The ability of a governmental institution to manage service recoveries is critical in preventing post-benefit inconvenience. If users perceive minimal loss of time and effort during recovery, post-benefit convenience will be increased (Berry et al., 2002). In this sense, the availability of service features permitting vendors to track or retrieve every recorded transaction can improve post-benefit convenience. Because Seiders et al.'s (2007) fivedimensional typology of service convenience resonates with past studies of critical success factors of e-government procurement systems, we therefore hypothesize that:

Hypothesis 2: Service convenience of an e-government procurement system comprises access, decision, transaction, benefit and post-benefit convenience.

\subsection{Types of Performance Failure of E-Government Procurement System}


Performance failure is a major deterrent for potential adopters of electronic services. Performance failure occurs whenever an e-service does not function as it promises, such as when information on a website is not displayed legibly, a transaction is not processed correctly or, a page does not load properly. Though performance failure can assume the form of binary events whereby a system can go offline completely so much so that users' beliefs on other aspects of the system (e.g., service convenience) may not matter to them, Tan et al. (2016) have uncovered that failure, in the context of electronic services, often falls on a spectrum varying in intensity. For example, a delay of a couple of seconds in page loading may be tolerable to some, but could be deemed unacceptable by others. Therefore, in line with the work of Tan et al. (2016), we construe performance failure as a spectrum that varies in intensity rather than as a binary concept.

Performance failures are especially pronounced for e-government systems in developing countries. For example, vendors in Indonesia not only encountered protracted delays when transacting with e-government procurement systems, they also protested that information on these systems was often outdated. Because any type of performance failure negatively affects user satisfaction, it is crucial for online service providers to identify and manage performance failure in a timely manner (Holloway and Beatty, 2003). While system success is derived from satisfying users' expectations on a consistent and recurring basis (Cenfetelli et al. 2008; Xu et al. 2013), performance failure constitutes a singular event that invokes dissatisfaction and/or negative emotional responses from users (DeWitt and Brady 2003: Hess et al. 2007; Kelley et al. 1993; Taylor 1994). For this reason, the importance of failure events cannot be understated because they are more likely to leave a lasting impression on system users due to heightened emotions, which in turn could culminate in a general reluctance to engage with a defective system (Tan et al. 2016). We therefore hypothesize that: 
Hypothesis 3: Performance failure of an e-government procurement system negatively affects vendors' satisfaction with the system.

To derive the types of performance failure relevant to this investigation, we draw on the parallel research stream of system success to identify critical determinants of failure for egovernment procurement systems. DeLone and McLean (1992, 2003) distinguished between information and system attributes as focal determinants of system success. Whereas information attributes capture the value of information generated by a system, system attributes are reflective of its technical performance (DeLone and McLean 1992, 2003). To a large extent, information and system attributes resonate with the conception of e-government services as a blend of service content and delivery components (Tan et al., 2013). Whereas service content depicts the range and sophistication of functions available from an e-government system in assisting citizens to complete their transactions, service delivery characterizes the manner by which these functions are made accessible via web interfaces as delivery channels (Tan et al., 2013). While system attributes are synonymous with the delivery aspects of services (see Collier and Bienstock, 2003, 2006; Fassnacht and Koese, 2006), information attributes constitute just one facet of service content because the function capabilities of technological systems are largely neglected as distinct but complementary elements of service content (Janda et al., 2002).

The concept of functionality has been employed to describe web-enabled functions that create value for consumers throughout the acquisition process of products and/or services (Cenfetelli et al., 2008; Lightner, 2004). Functionalities are distinguishable from information attributes in that they reflect service applications that generate and tailor transactional information to fit the requirements of individual consumers (Cenfetelli et al., 2008; EtezadiAmoli and Farhoomand, 1996; Janda et al., 2002; Lightner, 2004). For instance, payment functionalities produce confirmation receipts verifying order information whereas tracking 
functionalities yield delivery details on the current whereabouts of purchased products. We therefore further differentiate between information and function attributes of e-services as constituent components making up the broader notion of service content and postulate that failures for e-government procurement systems may be delineated into those associated with the information, function, or system aspects of e-services. Furthermore, unlike the behavioral-based belief of service convenience, information, function and system attributes are intrinsic to egovernment procurement systems and can thus be treated as object-based beliefs of citizens. In line with the compatibility principle, we hypothesize that:

Hypothesis 4: Performance failure of an e-government procurement system stems from information, function and system failures.

The remainder of this section will examine information, function and system failures in greater detail to: (1) arrive at viable working definitions, and; (2) explicate the impact of performance failure on vendors' perceptions of service convenience and satisfaction with egovernment procurement systems.

Information Failure: The saliency of information attributes in determining system output is well documented (DeLone and McLean, 2003; Wixom and Todd, 2005). Empirical studies have linked information attributes to a host of positive benefits for task accomplishments such as workplace performance (Goodhue and Thompson, 1995; Saunders and Jones, 1992), productivity enhancements (Northrop et al., 1990), decisional quality (Wixom and Watson, 2001), system satisfaction (Etezadi-Amoli and Farhoomand, 1996), and improvements to work environment (Teo and Wong, 1998). There is an abundance of empirical evidence within service and system success literatures (e.g., Bailey and Pearson, 1983; Ives et al., 1983; Baroudi and Orlikowski, 1988; Doll and Torkzadeh, 1988) that bear witness to the importance of information attributes in directing system outcomes. This is also borne out in the work of Holloway and 
Beatty (2003), which discovered that information failures capture a significant fraction of design problems that users associate with e-services. We therefore posit that information failure would constitute a major deficiency of e-government procurement systems and that it occurs whenever information provided via an e-government procurement system is incapable of guiding vendors in bidding for public tenders. For instance, if an e-government procurement system were to display inaccurate information about the bidding process, vendors could be misled and ended up expending unnecessary time and effort when participating in public tenders.

Function Failure: Homburg et al. (2002) observed that service content quality is instrumental in shaping positive user reactions by ensuring constant support throughout the entire transactional process. The provision of timely assistance to customers from pre- to posttransactional stages can only be realized through the appropriation of technology, especially with regards to the nurturing of a personalized service experience (Cenfetelli et al., 2008; Pan et al. 2006). The same can be said for e-governments. Through leveraging information technologies, governments can overcome physical barriers and resource constraints in personalizing public services, while simultaneously increasing the number of contact points between governmental institutions and citizens (Lim et al., 2007; Pan et al., 2006). In this sense, e-government systems present opportunities for governmental institutions to leverage web technologies in offering customizable service content that caters to citizens' requirements at every stage of the transactional process (Ho, 2002; Tan and Pan, 2003; Tan et al., 2005). Indeed, the provision of user-centric functionalities to cater to users' service expectations has been advocated and empirically corroborated for e-government services (Tan et al., 2013). We therefore define function failure to have occurred whenever functions provided via an e-government procurement system are incapable of supporting vendors in bidding for public tenders. For 
instance, if the bidding function for an e-government procurement system were to go offline, vendors participating in public tenders may be compelled to forego their current session and return at a later stage, thereby incurring extra time and effort.

System Failure: System quality has been demonstrated to improve workplace conditions (Goodhue and Thompson, 1995; Teo and Wong, 1998) and streamline decision-making processes (Wetherbe, 1991; Wybo and Goodhue, 1995) through enhanced adaptability to changing information needs (Vandenbosch and Huff, 1997; Wixom and Watson, 2001). System attributes, in the likes of accessibility, navigability and loading speed, govern the dissemination of service content via e-government systems and are instrumental in alleviating the transactional burden of users by reducing the amount of cognitive effort expended in accessing e-services (Lim et al., 2012; Tan et al, 2013). The absence of key system attributes may thus undermine the delivery of service content for online transactions and lead to unnecessary complications of the online transactional process for users (Cenfetelli et al., 2008). That is, low system quality may lead users to detect minimal differences between e-government systems and offline channels or in extreme cases, to view the former as being an inferior transactional medium as compared to the latter (Tan et al., 2013). We hence define system failure to have occurred whenever service content (i.e., information and functions) offered via an e-government procurement system is not delivered in a conducive manner that facilitates vendors in bidding for public tenders. For instance, if an e-government procurement system is experiencing lags when loading pages, vendors participating in public tenders would be forced to wait much longer to complete a transaction, culminating in wasted time and effort. Conceivably, we can infer from the preceding discussion that performance failure will adversely influence vendors' perceptions of service 
convenience when transacting with e-government procurement systems. We therefore hypothesize that:

Hypothesis 5: Performance failure of an e-government procurement system negatively affects vendors' perceived service convenience with the system.

\section{Method}

Our theoretical model was validated based on survey data gathered from experienced vendors of an e-government procurement system developed by the Indonesian government. In 2004, the first e-government procurement system, called the National e-Procurement Government of Indonesia (NePGI) was funded and established by the World Bank. The objective of the e-government procurement system is to promote good governance by eradicating corruption while increasing transparency and accountability. The Ministry of Communication and Information Technology, which managed the system, developed it further and changed the name of the system to Sistem e-Pengadaan Pemerintah / System of Electronic Government Procurement (SePP) in 2006. Subsequently, the system was promoted as an alternative option for public procurement to many central and local governmental institutions (e.g., Ministry of Agriculture and Province of Banten). SePP is an application that houses modules for different procurement activities (e.g., e-announcement, e-tendering, e-purchasing and e-selection). All vendors and governmental institutions across Indonesia, either central or local, can utilize services provided by SePP, once they are registered in the system. Since the ministry simplified and updated the system, the number of vendors registered in the SePP has increased from 150 in 2007 to more than 4,445 in 2012.

To begin, a questionnaire was developed to assess vendors' experience with the SePP. In line with our research model (see Figure 1), the e-government procurement system was assessed according to the five dimensions of service convenience, three types of performance failure, and 
satisfaction. Each of these constructs comprises three measurement items based on a five-point Likert scale with $1=$ strongly disagree, $2=$ disagree, $3=$ neutral, $4=$ agree, $5=$ strongly agree . The items are mostly adapted from past studies to ensure content validity. First, items for the five dimensions of service convenience and user satisfaction were adapted from prior research in marketing (Seiders et al., 2007). Second, we developed measures for the three constructs of performance failure in which items for two of them (i.e., information and system failures) were modified from DeLone and McLean (2003) and Wang and Liao (2008). Although DeLone and McLean (2003) and Wang and Liao (2008) focused on system success, items associated with information quality and system quality could be adapted to measure performance failure, because failure in any given information or system attribute diminishes user satisfaction (Tan et al., 2016). Conversely, service quality, as advocated in past studies of system success, was not retained, because it pertains to users' overall service experience and as such, is not directly affiliated with the performance failure of a system. Instead, we turned to measures for the multi-dimensional construct of service convenience from Seiders et al. (2007) as a better gauge of users' overall service experience. Furthermore, we incorporated newly created measurement items for the construct of function failure because as highlighted above, function failure constitutes a salient but neglected aspect of performance failure in systems.

For all measurement items, the wording has been revised to fit the context of an egovernment procurement system. Additionally, we have taken necessary steps to validate the measurement items in accordance with the sorting procedures outlined by Moore and Benbasat (1991), especially for the newly created measures related to function failure. For the sorting exercise, three independent judges were recruited. Each judge was presented with definitions for each of the abovementioned nine constructs (i.e., access convenience, decision convenience, 
transaction convenience, benefit convenience, post-benefit convenience, information failure, system failure, function failure, and satisfaction) and a randomly sorted list of twenty-seven reflective items on cue cards. The judges were then told to independently assign each item to one of the nine constructs or to an 'ambiguous' category if they were unsure of its placement. As can be deduced from Appendix A, a hit ratio of $95.06 \%$ was attained across the three judges, thereby indicating that judges, on average, were able to correctly associate at least nine out of ten items with their respective latent constructs with high fidelity. That is, other than the constructs of decision convenience, transaction convenience, benefit convenience, and post-benefit convenience for which one item each was incorrectly associated with a separate latent construct (see Appendix A), judges were able to match the remaining items with the latent construct each item supposedly reflects. Through the sorting exercise, we can be relatively confident that the measurement items demonstrate sufficient convergent and discriminant validity because the judges, as a collective, were not only able to group the items measuring the same latent construct together, they can also distinguish the items measuring one latent construct from those measuring another (see Appendix A). Apart from the measurement items for focal constructs in our research model, the survey also contained questions about vendors' corporate information such as annual income, age, location, number of employees, and usage of SePP services.

Prior to the launch of the survey, a face-to-face pretest was conducted on a smaller scale. The goal of the pretest was to discern the clarity of the survey and reliability of the measurement items. Before the pretest, the questionnaire was translated into Indonesian by an individual with language proficiency in both Indonesian and English. Next, another independent individual fluent in both Indonesian and English language translated the questionnaire back into English. The retranslated questionnaire was compared with the original measurement items phrased in 
English to ensure that the meanings of items were not distorted. For the pretest, we distributed 100 paper-based questionnaires at the helpdesk office of SePP, leading to a sample of 40 responses. Apart from minor changes to the wording of a few items, no major issue surfaced during the pretest. Due to the changes, responses from the pretest were not included in our data analysis. Appendix $B$ summarizes the eventual list of measurement items included in the questionnaire for the actual survey.

A field survey was conducted for months. Respondents were solicited through email. After the first invitations were distributed, follow-up emails were sent to non-respondents, but no more than twice. The list of email addresses was acquired from SePP's administration database. We emailed 1,400 vendors. While 246 vendors started the online survey, 227 vendors completed all stages of the online survey. Consequently, we analyzed these 227 data points via a Structural Equation Modelling (SEM) technique. Table 1 summarizes the descriptive characteristics of vendors, who answered the survey.

\section{$<<$ Table 1 >}

\section{Data Analysis}

To validate both the measurements and structural properties of our research model, we analyzed the properties of our measurement model and structural model via SmartPLS 2.0. The software offers Partial Least Squares (PLS) analysis to facilitate the modeling of both formative and reflective constructs.

Due to the fact that survey method can be plagued by common method bias, Exploratory Factor Analysis (EFA) of the 27 variables was performed with Harman's (1967) one-factor extraction test. Common method bias was not found to be a threat since no single factor accounts for more than 50\% of total variance (Schriesheim, 1979). 
For the measurement model, we computed internal consistency, inter-construct correlation, and item reliability to ascertain both convergent and discriminant validity (Fornell and Larcker, 1981). First, Cronbach's alpha $(\alpha)$ for each latent variable was calculated. Cronbach's alpha must exceed 0.70 to be considered reliable. All latent variables met this requirement. Second, we computed composite reliability to assess the internal consistency of latent variables. Composite reliability is the amount of scale score variance that is accounted for by all underlying factors (Brunner and Sub, 2005). Third, the Average Variance Extracted (AVE) for each latent variable was calculated to evaluate convergent validity. Average Variance Extracted, as proposed by Fornell and Larcker (1981), is a measure of the percentage of variance for a latent variable that is explained by its measurement item(s). Each latent variable has composite reliability and AVE higher than Fornell and Larcker's (1981) recommended thresholds of 0.70 and 0.50 respectively (Table 2). Fourth, item reliability was established by inspecting the mean and factor loading for individual items (Appendix B).

\section{$<<$ Table 2>>}

Fifth, we also computed the square root of AVE to obtain discriminant validity in which the square root of AVE for a latent variable should be greater than its correlation with any other variable (Table 3). As shown in Table 3, it is apparent that convergent and discriminant validity holds for each latent variable because the square root of AVE not only exceeds 0.50 for each latent variable, but it is also greater than the inter-correlations between the latent variable and any other variables. After inter-correlations among constructs were validated, the correlation between the two items of FUN1 and TRA 1 were tested, because survey questions for the two items looked similar. The average measure of correlation between FUN1 and TRA1 is - 0.269 
with insignificance $(\rho=1.000)$. We hence conclude that the two items of FUN1 and TRA1 are not related to each other.

\section{$<<$ Table 3>>}

To validate our structural model (Figure 2), we modeled service convenience as a secondorder, aggregate construct consisting of five first-order reflective constructs (i.e., access, decision, transaction, benefit, and post-benefit convenience) as suggested by Seiders et al. (2007). In addition, we modeled performance failure as a second-order, aggregate construct consisting of the three first-order constructs of information failure, function failure and system failure. Furthermore, multicollinearity was tested among the three variables (i.e., information, function and system failure) with the variance inflation factor (VIF). The VIFs are 2.66, 4.68 and 3.04 for information, function, and system failure respectively. These values are not significant enough to threaten the validity of our empirical findings.

\section{$<<$ Figure 2>>}

The multi-dimensional nature of service convenience is confirmed by the empirical evidence. The formative paths of the five service convenience dimensions were statistically significant: access $(\beta=0.206, \rho<0.001)$, decision $(\beta=0.229, \rho<0.001)$, transaction $(\beta=$ 0.228, $\rho<0.001)$, benefit $(\beta=0.207, \rho<0.001)$, and post-benefit $(\beta=0.234, \rho<0.001)$ convenience. Likewise, the formative paths of the three types of performance failure were statistically significant: information $(\beta=0.337, \rho<0.001)$, function $(\beta=0.385, \rho<0.001)$, and system $(\beta=0.369, \rho<0.001)$ failure. Hypotheses 2 and 4 are thus corroborated by the empirical evidence.

Service convenience $(\beta=0.699, \rho<0.001)$ exerts positive and significant effects on vendor satisfaction whereas the reverse is true for performance failure $(\beta=-0.152, \rho<0.01)$. Together, 
service convenience and performance failure account for $63.9 \%$ of explained variance in vendor satisfaction. Hypotheses 1 and 3 are hence supported. Last but not least, performance failure ( $\beta$ $=-0.600, \rho<0.01)$ exerts negative and significant effects on vendors' perceived service convenience, thereby substantiating Hypothesis 5. This path accounts for $36.0 \%$ of explained variance for service convenience.

\subsection{Post-hoc Analysis}

From our analysis of the structural model, we discovered that performance failure and service convenience exert significant but opposite effects on satisfaction, but we also found that performance failure negatively affects service convenience. Conceivably, the preceding analytical results hint that it is plausible for information, function, and system failure to exert differential effects on each of the five dimension of service convenience. Therefore, to clarify the relationship between each type of performance failure and a specific dimension of service convenience, we further analyzed a model that embodies separate relationships between the three types of performance failure and the five dimensions of service convenience (Figure 3).

\section{$<<$ Figure 3>>}

Information failure exerts negative and significant effects on all dimensions of service convenience: $\beta=-0.089$ with $\rho<0.05$ on access, $\beta=-0.313$ with $\rho<0.001$ on decision, $\beta=-$ 0.206 with $\rho<0.001$ on transaction, $\beta=-0.233$ with $\rho<0.001$ on benefit, and $\beta=-0.134$ with $\rho$ $<0.01$ on post-benefit.

Function failure exerts negative and significant effects on all dimensions of service convenience except for benefit convenience: $\beta=-0.235$ with $\rho<0.001$ on access, $\beta=-0.147$ with $\rho<0.01$ on decision, $\beta=-0.104$ with $\rho<0.05$ on transaction, $\beta=-0.042$ with $\rho>0.05$ on benefit, and $\beta=-0.280$ with $\rho<0.001$ on post-benefit. 
System failure exerts negative and significant effects on all the dimensions of service convenience: $\beta=-0.206$ with $\rho<0.001$ on access, $\beta=-0.161$ with $\rho<0.001$ on decision, $\beta=-$ 0.296 with $\rho<0.001$ on transaction, $\beta=-0.313$ with $\rho<0.001$ on benefit, and $\beta=-0.243$ with $\rho$ $<0.001$ on post-benefit. These three paths explain $24.2 \%, 32.2 \%, 30.4 \%, 28.6 \%$, and $36.8 \%$ of the variance for access, decision, transaction, benefit, and post-benefit convenience respectively.

\section{Discussion}

This study advances a model that sheds lights on how e-government procurement systems may be designed from a vendor-centric perspective based on behavioral aspects of service convenience and objective system attributes. Specifically, we posit that the presence of performance failure for e-government procurement systems negatively affects vendors' satisfaction even though the opposite effect can be discerned for service convenience. In addition, each type of performance failure negatively impacts all the dimensions of service convenience, thereby culminating in reduced satisfaction for vendors.

\subsection{Key Empirical Findings and Insights}

Results from a survey of 227 vendors reveal several interesting findings. First, our theoretical model appears to be relatively robust in predicting vendors' satisfaction with egovernment procurement systems given that our hypothesized relationships are corroborated based on empirical evidence (see Figure 2).

Second, performance failure and service convenience are strong predictors of vendors' satisfaction with e-government procurement systems, explaining $63.9 \%$ of variance in the latter (see Figure 2). This implies that performance failure and service convenience constitute primary concerns of vendors in the adoption of e-government procurement systems. Additionally, each of the five constituent dimensions of service convenience (i.e., access, decision, transaction, benefit 
and post-benefit) can be deemed as being equally salient in light of their almost equivalent path coefficients, even though the beta values for post benefit $(\beta=0.234)$, decision $(\beta=0.229)$, and transaction $(\beta=0.228)$ are slightly higher than those for access $(\beta=0.206)$ and benefit $(\beta=$ 0.207) (see Figure 2).

\section{$<<$ Table 4>>}

Finally, it is clear from Figure 2 that information, function and system failures negatively influence vendors' satisfaction of e-government procurement systems. This is also reflected in our post-hoc analysis whereby information, function and system failures exert significant and negative effects on each of the five constituent dimensions of service convenience with the sole exception coming from the non-significant impact of function failure on benefit convenience (see Table 4). A plausible reason behind such an observation may be because benefit convenience deals with the extent to which vendors are able to obtain desired outcomes from utilizing egovernment procurement systems whereas function failure relates to problems with transactional functionalities that constitute the process. For instance, a core benefit of e-government procurement system lies in the transparency of the bidding process. This can only be attained through the provision of information on the status of different tenders and is not so much dependent on the available of a submission function for bids. Therefore, even if certain functions are unavailable to vendors, it may not necessarily dictate the outcome of an e-government procurement system.

\subsection{Implications for Theory}

From a theoretical standpoint, this study contributes to extant literature on G2B egovernment, especially with respect to e-procurement in developing countries. 
Prior research on G2B e-government has progressed in a lopsided fashion with comparatively fewer studies on the demand side than those on the supply side (Lim et al., 2012). As discovered in our review of extant literature, the majority of past studies (e.g., Obeidat and Abu-Shanab, 2010; Panayiotou et al., 2004; Tung and Rieck, 2005) have centered on the operational benefits of pursuing G2B e-government initiatives for governmental institutions and neglected to take into consideration the receptivity of participating organizations, much less in a developing country. To fill this gap, we investigate an e-government procurement system in a developing country from the demand perspective. By postulating performance failure and service convenience as focal determinants of vendors' satisfaction towards e-government procurement systems, we construct and validate a theoretical model that builds on and extends contemporary knowledge of e-government systems. Specifically, although convenience has been touted as a critical success factor of e-government systems in prior research (e.g., Mirchandani et al., 2008) by enhancing the desirability of such systems through improved ease of use and performance (e.g., Alshawi and Alalwany, 2009; Seo and Bernsen, 2016), it is often treated as a unidimensional construct. In contrast, we advance a multi-dimensional view of service convenience that is contextualized to e-government procurement systems. In doing so, this study connects service marketing literature to e-government research. Since e-business and ecommerce theories have been applied extensively within extant literature on e-government (e.g., Kumar and Peng, 2006; Obeidat and Abu-Shanab, 2010; Schubert and Häusler, 2001), this study illustrates how concepts from service marketing can be applied to explain and predict vendors' satisfaction with e-government procurement systems.

At the same time, we reveal that performance failure, as a composition of information, function and system failures, negatively influences vendors' satisfaction with e-government 
procurement systems. In addition, results from post-hoc analysis attest to Wixom and Todd's (2005) proposition of a direct relationship between object- and behavioral-based beliefs. But at the same time, two aspects distinguish our study from prior research (e.g., Prybutok et al., 2008). One, we testify to the impact of negative object-based beliefs on behavioral-based beliefs. Whereas the three types of performance failure constitute objective-based beliefs about defective technological components of e-government procurement systems, the five dimensions of service convenience represent behavioral-based beliefs that pertain to the meaning and purpose of utilizing these systems. Two, going beyond conventional studies (e.g., Lee et al., 2009; Seo and Bernsen, 2016; Verdegem and Verleye, 2009) which focus primarily on individualized actions, we illustrate that the compatibility principle, as advocated by Ajzen (1988), is equally applicable in predicting organizational behaviors. In this sense, our findings not only expand on the work of Wixom and Todd (2005) by proving that the relationship between object- and behavioral-based beliefs is not constrained by its direction, but we also showcase the criticality of delineating between object- and behavioral-based beliefs for organizational-level studies.

In developing countries, governments are still coping with the early implementation of eprocurement systems that tend to be of low quality (UNCTAD secretariat, 2003). With limited resources, these governments are struggling to optimize their resources in developing and implementing e-procurement systems. Our study contributes to an in-depth appreciation of key considerations in the design and evaluation of e-government procurement systems. By recognizing the service expectations of vendors from a demand angle, governments can design more convenient websites while at the same time, maintaining vigilance against performance failure. While the utilization of e-government procurement systems is not compulsory and exposes low awareness in developing countries (Heeks, 2006), it is still vital to attract potential 
vendors. To do so, governments should strive to enhance the quality of e-government websites by improving service convenience and minimizing performance failure. Due to limited resources, governments often have to decide on the urgency of tackling specific service dimensions whenever vendors encounter any form of performance failure and service inconvenience. For this reason, findings from this study can guide governments in optimizing resource allocation: as system failure and post-benefit convenience appear to be the strongest indicators of e-government procurement systems, governments need to pay close attention to these elements over time.

Finally, through our post-hoc analysis, we uncover how each type of performance failure adversely affects vendors' perception of each dimension of service convenience for egovernment procurement systems. Our findings suggest that system failure plays an instrumental

role in shaping vendors' evaluation of service convenience for e-government procurement systems. On the other hand, while information failure is specifically related to the dimensions of decision, transaction and benefit convenience, function failure is particularly influential in driving vendors' perceptions of access and post-benefit convenience. In turn, this opens a new avenue for investigating the relationships between types of performance failure and dimensions of service convenience in the future.

\subsection{Implications for Practice}

Findings from this study could be of interest to practitioners for two reasons. First, the three types of performance failure (i.e., information, function and system) as well as the five constituent dimensions of service convenience serve as actionable design principles that can be harnessed by governmental institutions in developing e-government procurement systems, which satisfy vendors' transactional requirements. Particularly, these eight design principles can be 
deployed to analyze service deficiencies in existing e-government procurement systems that may warrant corrective actions on the part of governmental institutions. Due to the negative influence of performance failure on both service convenience and vendor satisfaction as indicated in our findings, it is recommended that governmental institutions in developing countries should first invest its limited resources to address issues with performance failure. Furthermore, even though the formative paths of the three types of performance failure are similar, we advise governmental institutions to concentrate on resolving issues with function failures before tackling other types of failures. This is because our study reveals that the adverse effect of function failure on performance appears to be the most pronounced among the three. Only when performance failures no longer pose a challenge, governmental institutions can turn their attention to enhancing service convenience. Specifically, improving post-benefit convenience can be a priority due to its predominant effect on vendors' evaluation of service convenience. For instance, governmental institutions can augment the post-benefit convenience of e-procurement systems by incorporating features that allow vendors to: (1) report transactional problems which transpire during the bidding process; (2) follow-up on the bidding process through online customer service support in the event of transactional failure, and; (3) monitor the current status of their bids once they have been entered into the system. This is especially true for the Indonesia government in that findings from this study can be harnessed in designing vendor-centric e-government procurement systems.

More importantly, our empirical investigation reveals that vendors participating in the SePP appear to be concentrated in Jakarta, a relatively developed region in terms of digital infrastructure. This may indicate that despite the accessibility of well-designed e-government procurement systems, corresponding investments in narrowing the digital divide of developing 
countries is necessary to foster adoption beyond developed regions. Similar conclusions were reached by Furuholt and Wahid (2008), Rose (2004), and Nurmandi and Kim (2015), who professed that regional governments in Indonesia have been slow in migrating to e-government due to a lack of supporting infrastructure and severe shortage in qualified technology professionals and human resources management.

\subsection{Limitations}

There are two main caveats to be noted for our empirical study. First, administering a survey on Indonesian respondents, who are not English educated, presents a major challenge in ensuring that the true meaning of the different constructs has been accurately captured. While we have taken every effort to ensure that the meaning of the measurement items, as originally conceived, remain intact during translation, we cannot guarantee that respondents were able to interpret the translated measures as intended. Future research is necessary to replicate our study in other developing countries to ascertain the validity of our empirical findings.

Second, the composition of the respondents within the sample also points to a need for caution in interpreting our empirical findings. From Table 1, it is clear that the sample is dominated by vendors that are located primarily in a specific region of the country (i.e. Jakarta) and are affiliated with a particular industrial sector (i.e. ICT, Electronic and Electricity). The composition of the sample however, is consistent with the actual composition of vendors registered for the e-government procurement system. Out of 4,445 companies registered for the SePP, $60 \%$ are located in Jakarta and this is roughly captured in our sample where $55 \%$ of respondents are situated in Jakarta. Yet, it could be the case that our empirical findings may not apply to other developing countries with distinctive geographical and economic configurations. For instance, there is a possibility that the relationships in our theoretical model are affirmed 
because respondents typically belong to firms that are at the forefront of technology. If we were to test our theoretical model on respondents from another developing country that is agriculturally based, we might arrive at different conclusions. Again, future research is warranted to refine and validate our theoretical model in other developing countries.

\section{Conclusion}

In summary, this study attempts to expand on extant literature on G2B e-government by putting forth service convenience as a precondition for vendors' satisfaction with e-government procurement systems. At the same time, we highlight the importance of monitoring egovernment procurement systems for signs of information, function and system failures. Such failures, when present, act as inhibitors affecting vendors' satisfaction and evaluation of service convenience with e-government procurement systems. 


\section{References}

1. Accenture. (2009). Leadership in customer service: Creating shared responsibility for better outcomes. The Government Executive Series.

2. Ajzen, I. (1988). Attitudes, personality, and behavior. Chicago, IL: Dorsey Press.

3. Ajzen, I., \& Fishbein, M. (1980). Understanding attitudes and predicting social behavior. Englewood Cliffs, NJ: Prentice-Hall.

4. Ajzen, I., \& Fishbein, M. (2005). The influence of attitudes on behavior. In D. Albarracín, B. T. Johnson, \& M. P. Zanna (Eds.), The handbook of attitudes (pp. 173-221). Mahwah, NJ: Erlbaum Publishers.

5. Alsaghier, H., Ford, M. Nguyen, A., \& Hexel, R. (2009). Conceptualising citizen's trust in e-government: Application of Q methodology. Electronic Journal of e-Government, 7(4), 295-310.

6. Alshawi, S., \& Alalwany, (2009). H. E-government evaluation: Citizen's perspective in developing countries. Information Technology for Development, 15(3), 193-208.

7. Andaleeb, S.S., \& Basu, A.K. (1994). Technical complexity and consumer knowledge as moderators of service quality evaluation in the automobile service industry. Journal of Retailing, 70(4), 367-381.

8. Awan, M. (2007). Dubai e-government: An evaluation of G2B websites. Journal of Internet Commerce, 6(3), 115-129.

9. Bailey, J.E., \& Pearson, S.W. (1983). Development of a tool for measuring and analyzing computer user satisfaction. Management Science, 29(5), 530-45.

10. Baroudi, J.J., \& Orlikowski, W.J. (1988). A short form measure of user information satisfaction: A psychometric evaluation and notes on use. Journal of Management Information Systems, 4(4), 44-59.

11. Berry, L.L., Seiders, K., \& Grewal, D. (2002). Understanding service convenience. Journal of Marketing, 66(3), 1-17.

12. Brunner, M., \& Sub, H.M. (2005). Analyzing the reliability of multidimensional measures: An example from intelligence research. Educational and Psychological Measurement, 65(2), 227-240.

13. Cenfetelli, R.T., Benbasat, I., \& Al-Natour, S. (2008). Addressing the what and how of online services: Positioning supporting-services functionality and service quality for business to consumer success. Information Systems Research, 19(2), 161-181.

14. Chang K., Chen, M., Hsu, C., \& Kuo, N. (2010). The effect of service convenience on post-purchasing behaviours. Industrial management \& Data Systems, 110(9), 1420-1443.

15. Chang, Y., \& Polonsky, M.J. (2012). The influence of multiple types of service convenience on behavioral intentions: The mediating role of consumer satisfaction in a Taiwanese leisure setting. International Journal of Hospitality Management, 31(1), 107118. 
16. Chen, A.J., Pan, S. L., Zhang, J., Huang, W. W., \& Zhu, S. (2009). Managing egovernment implementation in China: A process perspective. Information \& Management, 46, 203-212.

17. Chen, Y.N., Chen, H.M., Huang, W., \& Ching, R.K.H. (2006). E-government strategies in developed and developing countries: An implementation framework and case study. Journal of Global Information Management, 14(1), 23-46.

18. Collier, J.E., \& Bienstock, C.C. (2003). A conceptual framework for measuring e-service quality. Academy of Marketing Science Conference Proceedings (pp. 158-162). Coral Gables, FL.

19. Collier, J.E., \& Bienstock, C.C. (2006). Measuring service quality in e-retailing. Journal of Service Research, 8(3), 260-275.

20. Colwell, S.R., Aung, M., Kanetkar, V., \& Holden, A.L. (2008). Toward a measure of service convenience: multiple-item scale development and empirical test. Journal of Services Marketing, 22(2), 160-169.

21. Croom, S., \& Jones, B. (2007). Impact of e-procurement: Experiences from implementation in the UK public sector. Journal of Purchasing \& Supply Management, 13(4), 294-303.

22. Dada, D. (2006). The failure of e-government in developing countries: Literature review. Electronic Journal of Information Systems in Developing Countries, 26(7), 1-10.

23. Davila, A., Gupta, M., \& Palmer, R. (2003). Moving procurement systems to the internet: The adoption and use of e-procurement technology models. European Management Journal, 21(1), 11-23.

24. DeBenedictis, A., Howell, W., Figueroa, R., \& Boggs, R.A. (2002). E-government defined: An overview of the next big information technology challenge. Issues in Information Systems, 3, 130-136.

25. DeLone, W.H., \& McLean, E.R. (1992). Information systems success: The quest for the dependent variable. Information Systems Research, 3(1), 60-95.

26. DeLone, W.H., \& McLean, E.R. (2003). The DeLone and McLean model of information systems success: A ten-year update. Journal of Management Information Systems, 19(4), $9-30$.

27. Devadoss, P.R., Pan, L.S., \& Huang, C.J. (2003). Structurational analysis of e-government initiatives: A case study of SCO. Decision Support Systems, 34(3), 253-269.

28. DeWitt, T., \& Brady, M. K. (2003). Rethinking service recovery strategies. Journal of Service Research, 6(2), 193-207.

29. Doll, W.J., \& Torkzadeh, G. (1988). The measurement of end-user computing satisfaction. MIS Quarterly, 12(2), 259-274.

30. Donthu, N., \& Garcia, A. (1999). The internet shopper. Journal of Advertising Research, $39(3), 52-58$.

31. Etezadi-Amoli, J., \& Farhoomand, A.F. (1996). A structural model of end user computing satisfaction and user performance. Information and Management, 30(1), 65-73. 
32. Fassnacht, M., \& Koese, I. (2006). Quality of electronic services: Conceptualizing and testing a hierarchical model. Journal of Service Research, 9(1), 19-37.

33. Fazio, R.H., \& Olson, M.A. (2003). Attitudes: Foundation, function and consequences, In, M.A. Hogg \& J. Cooper, (Eds.) The Sage Handbook of Social Psychology (pp. 123-145). London, UK: Sage.

34. Fishbein, M., \& Ajzen, I. (1975). Belief, attitude, intention and behavior: An introduction to theory and research. Reading, MA: Addison-Wesley.

35. Fornell, C., \& Larcker, D.F. (1981). Evaluating structural equation models with unobservable variables and measurement error. Journal of Marketing Research, 18(1), 3950.

36. Furuholt, B., \& Wahid, F. (2008). E-government challenges and the role of political leadership in Indonesia: The case of Sragen. In Proceedings of the $41^{\text {st }}$ Annual Hawaii International Conference on System Sciences, IEEE Computer Society, 411-411.

37. Goodhue, D.L., \& Thompson, R.L. (1995). Task-technology fit and individual performance. MIS Quarterly, 19(2), 213-236.

38. Gotoh, R. (2008). Assessing performance of e-government services for business users. In Proceedings of the 4th International Conference on e-Government (pp. 161-170). Melbourne, Australia: RMIT University.

39. Gunasekaran, A., \& Ngai, E.W.T. (2008). Adoption of e-procurement in Hong Kong: An empirical research. International Journal of Production Economics, 113(1), 159-175.

40. Hamilton, S., \& Chervany, N.L. (1981). Evaluating information system effectiveness - part I: Comparing evaluation approaches. MIS Quarterly, 5(3), 55-69.

41. Harman, H.H. (1967). Modern factor analysis. Chicago, IL: University of Chicago Press.

42. Heeks, R. (2006). Information systems and developing countries: Failure, success, and local improvisations. The Information Society, 18(2), 101-112.

43. Hess Jr., R. L., Ganesan, S., \& Klein, N. M. (2007). Interactional service failures in a pseudorelationship: The role of organizational attributions. Journal of Retailing, 83(1), 7995.

44. Ho, A.T-K. (2002). Reinventing local governments and the e-government initiative. Public Administration Review, 62(4), 434-444.

45. Holloway, B.B., \& Beatty, S.E. (2003). Service failure in online retailing: A recovery opportunity. Journal of Service Research, 6(1), 92-105.

46. Homburg, C., Hoyer, W.D., \& Fassnacht, M. (2002). Service orientation of a retailer's business strategy: Dimensions, antecedents, and performance outcomes. Journal of Marketing, 66(4), 86-101.

47. Ives, B., Olson, M., \& Baroudi, J.J. (1983). The measurement of user information satisfaction. Communications of the ACM, 26(10), 785-793.

48. Janda, S., Trocchia, P.J., \& Gwinner, K.P. (2002). Consumer perceptions of internet retail service quality. International Journal of Service Industry Management, 13(5), 412-431. 
49. Kelley, S. W., Hoffman, K. D., \& Davis, M. A. (1993). A typology of retail failures and recoveries. Journal of Retailing, 64(4), 429-452.

50. Kumar, N., \& Peng, Q. (2006). Strategic alliances in e-government procurement. International Journal of Electronic Business, 4(2), 136-145.

51. Layne, K., \& Lee, J. (2001). Developing fully functional e-government: A four-stage model. Government Information Quarterly, 18(2), 122-136.

52. Lee, C., Gim, G., \& Yoo, B. (2009). The effect of relationship quality on citizen satisfaction with electronic government services. Marketing Management Journal, 19(2), $118-129$.

53. Liao, T.S., Wang, M.T., \& Tserng, H.P. (2002). A framework of electronic tendering for government procurement: A lesson learned in Taiwan. Automation in Construction, 11(6), $731-742$.

54. Lightner, N.J. (2004). Evaluating e-commerce with a focus on customer. Communications of the ACM, 47(10), 88-92.

55. Lim, E.T.K., Tan, C.W., Cyr, D., Pan, S.L., \& Bo, X. (2012). Advancing public trust relationships in electronic government: The Singapore e-filing journey. Information Systems Research, 23(4), 1110-1130.

56. Lim, E.T.K., Tan, C.W., \& Pan, S.L., (2007). E-government implementation: Balancing collaboration and control in stakeholder management. International Journal of Electronic Government Research, 3(2), 1-28.

57. Mahmood, S.A.I. (2010). Public procurement and corruption in Bangladesh confronting the challenges and opportunities. Journal of Public Administration and Policy Research, 2(6), 103-111.

58. Mirchandani, D.A., Johnson, J.H., \& Joshi, K. (2008). Perspectives of citizens towards egovernment in Thailand and Indonesia: A multigroup analysis. Information Systems Frontiers, 10(4), 483-497.

59. Moon, M.J. (2005). E-procurement management in state governments: Diffusion of eprocurement practices and its determinants. Journal of Public Procurement, 5(1), 54-72.

60. Moore, G.C., \& Benbasat, I. (1991). Development of an instrument to measure the perceptions of adopting an information technology innovation. Information Systems Research, 2(3), 192-222.

61. Northrop, A., Kraemer, K.L., Dunkie, D., \& King, J.L. (1990). Payoffs from computerization: Lessons over time. Public Administration Review, 50(5), 505-514.

62. Nurmandi, A., \& Kim, S. (2015). Making e-procurement work in a decentralized procurement system: A comparison of three Indonesian cities. International Journal of Public Sector Management, 28(3), 198- 220.

63. Obeidat, R.A., \& Abu-Shanab, E.A. (2010). Drivers of e-government and e-business in Jordan. Journal of Emerging Technologies in Web Intelligence, 2(3), 204-211.

64. Pan, S.L., Tan, C.W., \& Lim, E.T.K. (2005). Customer relationship management (CRM) in egovernment: A relational perspective. Decision Support Systems, 42(1), 237-250. 
65. Panayiotou, N.A., Gayialis, S.P., \& Tatsiopoulos, I.P. (2004). An e-procurement system for governmental purchasing. International Journal of Production Economics, 90(1), 79-102.

66. Prybutok, V.R., Zhang, X., \& Ryan, S.D. (2008). Evaluating leadership, IT quality, and net benefits in an e-government environment, Information \& Management, 45, 143-152.

67. Rose, M. (2004). Democratizing information and communication by implementing egovernment in Indonesian regional government, International Information \& Library Review, 36(3), 219-226.

68. Saunders, C.S., \& Jones, J.W. (1992). Measuring performance of the information systems function. Journal of Management Information Systems, 8(4), 63-82.

69. Schriesheim, C. A. (1979). The similarity of individual directed and group directed leader behavior descriptions. Academy of Management Journal, 22(2), 345-355.

70. Schubert, P., \& Häusler, U. (2001). E-Government meets e-business: A portal site for startup companies in Switzerland. In Proceedings of the 34th Hawaii International Conference on System Sciences, IEEE Computer Society (pp. 1700-1708). Los Alamitos, CA.

71. Seiders, K., Voss, G.B., Godfrey, A.L., \& Grewal, D. (2007). SERVCON: Development and validation of a multidimensional service convenience scale. Journal of the Academic Marketing Science, 35(1), 144-156.

72. Seifert, J.W., \& Petersen, R.E. (2002). The promise of all things e? expectations and challenges of emergent electronic government. Perspectives on Global Development and Technology, 1(2), 193-212.

73. Seo, D., \& Bernsen, M. (2016). Comparing behavioral attitudes toward e-government of non-users versus users in a rural versus an urban Municipality. Government Information Quarterly, 33(2), 270-282.

74. Siau, K., \& Long, Y. (2009). Factors impacting e-government development. Journal of Computer Information Systems, 50(1), 98-107.

75. Szymanski, D.M., \& Hise, R.T. (2000). E-satisfaction: An initial examination. Journal of Retailing, 76(3), 309-322.

76. Tan, C.W., \& Benbasat, I. (2009). IT mediated customer services in e-government: A citizen's perspective. Communications of the Association for Information Systems, 24(12), 175-198.

77. Tan, C.W., Benbasat, I., \& Cenfetelli, R.T. (2013). IT-mediated customer service content and delivery in electronic governments: An empirical investigation of the antecedents of service quality. MIS Quarterly, 37(1), 77-109.

78. Tan, C.W., Benbasat, I., \& Cenfetelli, R. (2016). An exploratory study of the formation and impact of electronic service failures. MIS Quarterly, 40(1), 1-29.

79. Tan, C.W., Pan, S.L., \& Lim, E.T.K. (2005) Managing stakeholder interests in egovernment implementation: Lessons learnt from a Singapore e-government project. Journal of Global Information Management 13(1), 31-53. 
80. Tan, C.W., \& Pan, S.L. (2003). Managing e-transformation in public sector: An egovernment study of Inland Revenue Authority of Singapore (IRAS). European Journal of Information Systems, 12(4), 269-281.

81. Taylor, S. (1994). Waiting to service: The relationship between delays and evaluations on service. Journal of Marketing, 58(2), 56-69.

82. Taylor, S., \& Todd, P.A. (1995). Assessing IT usage: The role of prior experience. MIS Quarterly, 19(2), 561-570.

83. Tang, J.E., \& Chiang, C. (2009). Perceived innovativeness, perceived convenience and TAM: Effects on mobile knowledge management. In Proceedings of the Third International Conference on Multimedia and Ubiquitous Engineering, (MUE '09), 413420.

84. Teo, T.S.H., \& Wong, P.K. (1998). An empirical study of the performance impact of computerization in the retail industry. International Journal of Management Science, $26(5), 611-621$.

85. Tung, L., \& Rieck, O. (2005). Adoption of electronic government services among business organizations in Singapore. Journal of Strategic Information Systems, 14(4), 417-440.

86. UNCTAD Secretariat. (2003). E-commerce and development report. New York and Geneva: United Nation Publication.

87. United Nations (UN). (2008). Global e-government survey 2008: From e-government to connected governance. New York and Geneva: United Nation Publication.

88. Vandenbosch, B., \& Huff, S.L. (1997). Searching and scanning: How executives obtain information from executive information systems. MIS Quarterly, 21(1), 81-107.

89. Verdegem, P., \& Verleye, G. (2009). User-centered e-government in practice: A comprehensive model for measuring user satisfaction. Government Information Quarterly, 26(3), 487-497.

90. Wang, R.Y., \& Strong, D.M. (1996). Beyond accuracy: What data quality means to data consumers. Journal of Management Information Systems, 12(4), 5-34.

91. Wang, Y.S., \& Liao, Y.W. (2008). Assessing e-government systems success: A validation of the DeLone and McLean model of information system success. Government Information Quarterly, 25(4), 717-733.

92. Wetherbe, J.C. (1991). Executive information requirements: Getting it right. MIS Quarterly, 15(1), 51-66.

93. Wirtz, B., Lütje, S., \& Schierz, P.G. (2010). An empirical analysis of the acceptance of eprocurement in the German public sector. International Journal of Public Administration, $33(1), 26-42$.

94. Wixom, B.H., \& Todd, P.A. (2005). A theoretical integration of user satisfaction and technology acceptance. Information Systems Research, 16(1), 85-102.

95. Wixom, B.H., \& Watson, H.J. (2001). An empirical investigation of the factors affecting data warehousing success. MIS Quarterly, 25(1), 17-41. 
96. Wybo, M.D., \& Goodhue, D.L. (1995). Using interdependence as a predictor of data standards: Theoretical and measurement issues. Information and Management, 29(6), 317330.

97. Xu, D., Benbasat, I., \& Cenfetelli, R. (2013). Integrating service quality with system and information quality: An empirical test in the e-service context. MIS Quarterly, 37(1), pp. 777-794. 
Appendix A






\section{Appendix B}

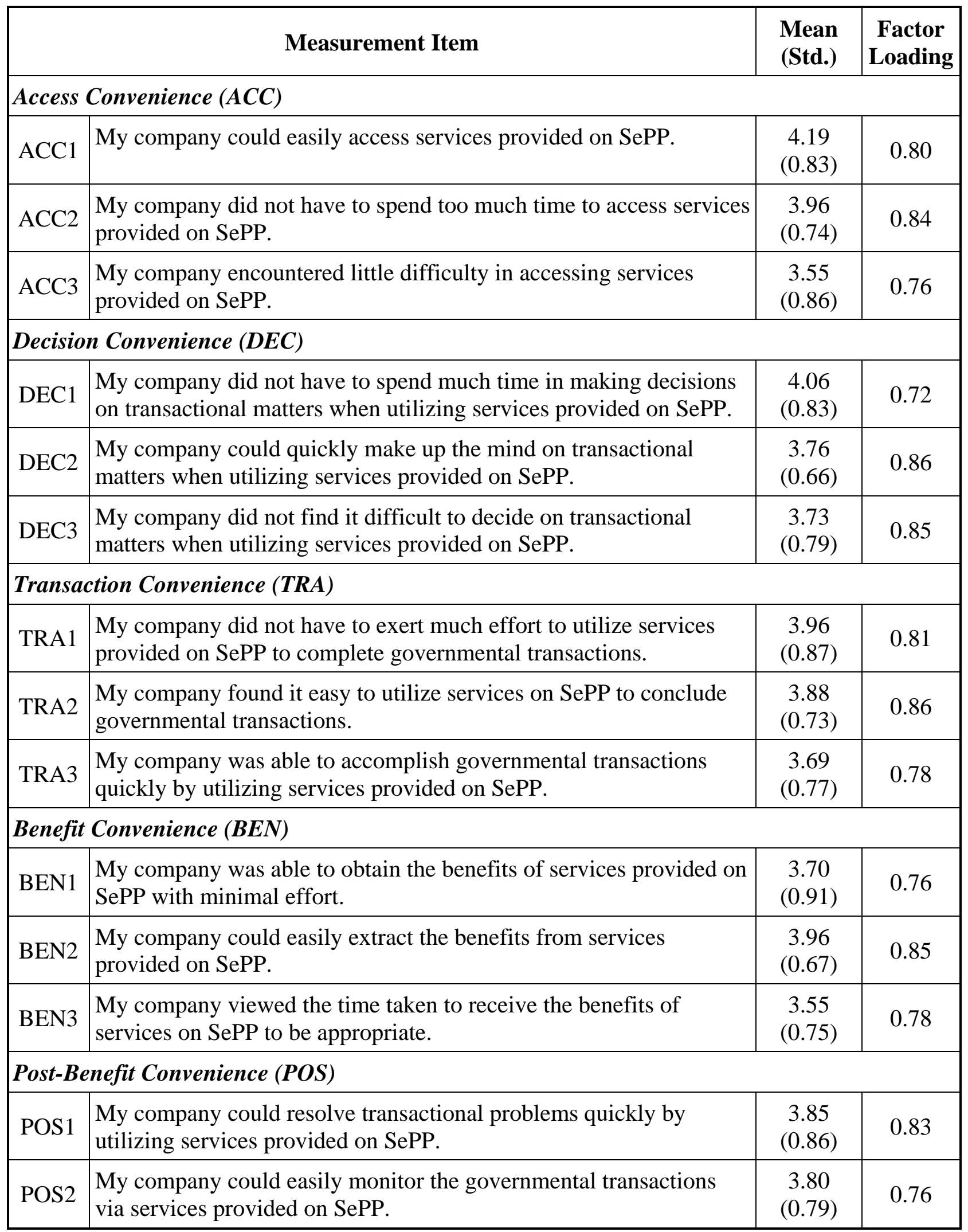




\begin{tabular}{|c|c|c|c|}
\hline POS3 & $\begin{array}{l}\text { My company found it easy to solve transactional problems by } \\
\text { utilizing services provided on SePP. }\end{array}$ & $\begin{array}{c}3.70 \\
(0.73)\end{array}$ & 0.85 \\
\hline \multicolumn{4}{|c|}{ Information Failure (INF) } \\
\hline INF1 & $\begin{array}{l}\text { Information provided on SePP was unable to help my company in } \\
\text { obtaining desired outcomes from governmental transactions. }\end{array}$ & $\begin{array}{c}2.46 \\
(0.88)\end{array}$ & 0.84 \\
\hline INF2 & $\begin{array}{l}\text { Information provided on SePP did not improve the outcomes my } \\
\text { company could attain from governmental transactions. }\end{array}$ & $\begin{array}{c}2.36 \\
(0.84)\end{array}$ & 0.78 \\
\hline INF3 & $\begin{array}{l}\text { Information provided on SePP was not useful to my company in } \\
\text { getting preferred outcomes from governmental transactions. }\end{array}$ & $\begin{array}{c}2.16 \\
(0.74)\end{array}$ & 0.83 \\
\hline \multicolumn{4}{|c|}{ System Failure (SYS) } \\
\hline SYS1 & $\begin{array}{l}\text { Service content on SePP was not readily accessible to my company } \\
\text { when conducting governmental transactions. }\end{array}$ & $\begin{array}{c}2.48 \\
(0.88)\end{array}$ & 0.82 \\
\hline SYS2 & $\begin{array}{l}\text { Service content on SePP did not load properly when my company } \\
\text { conducting governmental transactions. }\end{array}$ & $\begin{array}{c}2.52 \\
(0.89)\end{array}$ & 0.84 \\
\hline SYS3 & $\begin{array}{l}\text { Service content on SePP was difficult to access when my company. } \\
\text { conducting governmental transactions }\end{array}$ & $\begin{array}{c}2.54 \\
(0.90)\end{array}$ & 0.82 \\
\hline \multicolumn{4}{|c|}{ Function Failure (FUN) } \\
\hline FUN1 & $\begin{array}{l}\text { Functions provided on SePP did not support my company in } \\
\text { conducting governmental transactions. }\end{array}$ & $\begin{array}{c}2.45 \\
(0.83)\end{array}$ & 0.81 \\
\hline FUN2 & $\begin{array}{l}\text { Functions provided on SePP made it difficult for my company to } \\
\text { conduct governmental transactions. }\end{array}$ & $\begin{array}{c}2.33 \\
(0.81)\end{array}$ & 0.84 \\
\hline FUN3 & $\begin{array}{l}\text { Functions provided on SePP were incapable of assisting my } \\
\text { company in conducting governmental transaction. }\end{array}$ & $\begin{array}{c}2.33 \\
(0.80)\end{array}$ & 0.84 \\
\hline \multicolumn{4}{|c|}{ Satisfaction (SAT) } \\
\hline SAT1 & Overall, my company was satisfied with SePP. & $\begin{array}{c}3.65 \\
(0.82)\end{array}$ & 0.84 \\
\hline SAT2 & Overall, my company was pleased with SePP. & $\begin{array}{c}3.81 \\
(0.74)\end{array}$ & 0.91 \\
\hline SAT3 & Overall, my company was delighted with SePP. & $\begin{array}{c}3.86 \\
(0.76)\end{array}$ & 0.89 \\
\hline
\end{tabular}


Table 1. Descriptive Statistics of Participating Vendors (Sample N = 227)

\begin{tabular}{|c|c|c|c|c|c|}
\hline $\begin{array}{l}\text { Number of } \\
\text { Employees }\end{array}$ & $\begin{array}{c}\text { \# of firms } \\
(\%)\end{array}$ & $\begin{array}{l}\text { Company Type } \\
\text { (product/service) }\end{array}$ & $\begin{array}{c}\text { \# of } \\
\text { firms } \\
(\%)\end{array}$ & $\begin{array}{l}\text { Company } \\
\text { Location }\end{array}$ & $\begin{array}{c}\# \text { of firms } \\
(\%)\end{array}$ \\
\hline$<20$ & $134(59.03)$ & $\begin{array}{l}\text { Agriculture and } \\
\text { Cattle }\end{array}$ & $4(1.76)$ & Aceh & $1(0.44)$ \\
\hline $20-50$ & $50(22.03)$ & Construction & $\begin{array}{c}48 \\
(21.15)\end{array}$ & Central Java & $1(0.44)$ \\
\hline $51-100$ & $20(8.81)$ & Consulting Services & $32(14.1)$ & DKI Jakarta & $\begin{array}{c}123 \\
(54.19)\end{array}$ \\
\hline \multirow[t]{2}{*}{$>100$} & $23(10.13)$ & $\begin{array}{l}\text { Tools and } \\
\text { Equipment }\end{array}$ & $\begin{array}{c}34 \\
(14.98)\end{array}$ & East Java & $10(4.41)$ \\
\hline & & $\begin{array}{l}\text { ICT, Electronic and } \\
\text { Electricity }\end{array}$ & $\begin{array}{c}70 \\
(30.84)\end{array}$ & Jakarta & $2(0.88)$ \\
\hline $\begin{array}{c}\text { Age of } \\
\text { Company }\end{array}$ & \begin{tabular}{|c|}
$\begin{array}{c}\text { \# of firms } \\
(\%)\end{array}$ \\
\end{tabular} & $\begin{array}{c}\text { Printing, Media and } \\
\text { Advertisement }\end{array}$ & $10(4.41)$ & Riau Island & $21(9.25)$ \\
\hline$<1$ year & $16(7.05)$ & Others & $\begin{array}{c}29 \\
(12.78)\end{array}$ & South Kalimantan & $1(0.44)$ \\
\hline $1-5$ years & $65(28.63)$ & & & South Sulawesi & $3(1.32)$ \\
\hline 6-10 years & $61(26.87)$ & Annual Revenue & $\begin{array}{c}\text { \# of } \\
\text { firms } \\
(\%)\end{array}$ & South Sumatera & $1(0.44)$ \\
\hline \multirow[t]{2}{*}{$>10$ years } & 85 (37.44) & $10-50$ million & $\begin{array}{c}33 \\
(14.54) \\
\end{array}$ & $\begin{array}{l}\text { East Nusa } \\
\text { Tenggara } \\
\end{array}$ & $2(0.88)$ \\
\hline & & $50-100$ million & $\begin{array}{c}25 \\
(11.01) \\
\end{array}$ & West Java & $52(22.91)$ \\
\hline Usage & \begin{tabular}{|c|}
$\begin{array}{c}\text { \# of firms } \\
(\%)\end{array}$ \\
\end{tabular} & $100-500$ million & $\begin{array}{c}41 \\
(18.06)\end{array}$ & West Sumatera & $6(2.64)$ \\
\hline 1-5 times & $72(31.72)$ & $\begin{array}{l}500 \text { million }-1 \\
\text { billion }\end{array}$ & $\begin{array}{c}34 \\
(14.98)\end{array}$ & Yogyakarta & $4(1.76)$ \\
\hline 6-10 times & $31(13.66)$ & $>1$ billion & $\begin{array}{c}89 \\
(39.21)\end{array}$ & & \\
\hline$>10$ times & $122(53.74)$ & Not Mentioned & $5(2.20)$ & $\begin{array}{c}\text { Respondent's } \\
\text { Position }\end{array}$ & $\begin{array}{c}\begin{array}{c}\text { \# of firms } \\
(\%)\end{array} \\
\end{array}$ \\
\hline \multirow[t]{3}{*}{$\begin{array}{c}\text { Not } \\
\text { Mentioned }\end{array}$} & $2(0.88)$ & & & Employee & $88(38.77)$ \\
\hline & & & & Manager & $\begin{array}{c}118 \\
(51.98)\end{array}$ \\
\hline & & & & Not Mentioned & $21(9.25)$ \\
\hline
\end{tabular}

Note: Employee refers to an individual within a vendor organization that is responsible for submitting bids via the SePP system 
Table 2: Factor Analysis and Reliability Statistics

\begin{tabular}{|l|c|c|c|}
\hline \multicolumn{1}{|c|}{ Construct } & $\begin{array}{c}\text { Cronbach's } \\
\text { Alpha } \\
(>\mathbf{0 . 7 0})\end{array}$ & $\begin{array}{c}\text { Composite } \\
\text { Reliability } \\
(>\mathbf{0 . 7 0})\end{array}$ & $\begin{array}{c}\text { Average } \\
\text { Variance } \\
\text { Extracted } \\
(>\mathbf{0 . 5 0 )}\end{array}$ \\
\hline $\begin{array}{l}\text { Experienced Accessed } \\
\text { Convenience }\end{array}$ & 0.72 & 0.84 & 0.64 \\
\hline Experienced Decision Convenience & 0.74 & 0.85 & 0.66 \\
\hline $\begin{array}{l}\text { Experienced Transaction } \\
\text { Convenience }\end{array}$ & 0.76 & 0.86 & 0.67 \\
\hline Experienced Benefit Convenience & 0.71 & 0.84 & 0.63 \\
\hline $\begin{array}{l}\text { Experienced Post-Benefit } \\
\text { Convenience }\end{array}$ & 0.75 & 0.85 & 0.66 \\
\hline Experienced Information Failure & 0.75 & 0.86 & 0.67 \\
\hline Experienced System Failure & 0.77 & 0.87 & 0.69 \\
\hline Experienced Function Failure & 0.77 & 0.87 & 0.69 \\
\hline Experienced Satisfaction & 0.86 & 0.91 & 0.78 \\
\hline
\end{tabular}

Table 3: Inter-Construct Correlation Matrix (*Square-root of Average Variance Extracted)

\begin{tabular}{|c|c|c|c|c|c|c|c|c|c|}
\hline & Access & Decision & Transaction & Benefit & $\begin{array}{c}\text { Post- } \\
\text { Benefit }\end{array}$ & Information & System & Function & Satisfaction \\
\hline Access & $0.80 *$ & & & & & & & & \\
\hline Decision & 0.72 & $0.81 *$ & & & & & & & \\
\hline Transaction & 0.78 & 0.73 & $0.82 *$ & & & & & & \\
\hline Benefit & 0.72 & 0.78 & 0.75 & $0.80 *$ & & & & & \\
\hline Post-Benefit & 0.74 & 0.78 & 0.79 & 0.79 & $0.81 *$ & & & & \\
\hline Information & -0.41 & -0.54 & -0.48 & -0.46 & -0.51 & $0.82 *$ & & & \\
\hline System & -0.45 & -0.47 & -0.50 & -0.49 & -0.55 & 0.65 & $0.83^{*}$ & & \\
\hline Function & -0.47 & -0.53 & -0.50 & -0.47 & -0.58 & 0.79 & 0.82 & $0.83^{*}$ & \\
\hline Satisfaction & 0.67 & 0.72 & 0.71 & 0.69 & 0.74 & -0.46 & -0.55 & -0.56 & $0.88^{*}$ \\
\hline
\end{tabular}


Table 4: Beta Coefficients from Post-Hoc Analysis

\begin{tabular}{|l|c|c|c|c|c|}
\hline $\begin{array}{r}\text { Service } \\
\text { Convenience } \\
\text { Performance } \\
\text { Failure }\end{array}$ & $\begin{array}{c}\text { Access } \\
\text { Convenience }\end{array}$ & $\begin{array}{c}\text { Decision } \\
\text { Convenience }\end{array}$ & $\begin{array}{c}\text { Transaction } \\
\text { Convenience }\end{array}$ & $\begin{array}{c}\text { Benefit } \\
\text { Convenience }\end{array}$ & $\begin{array}{c}\text { Post-Benefit } \\
\text { Convenience }\end{array}$ \\
\hline Information Failure & $-0.089^{*}$ & $-0.313^{* * *}$ & $-0.206^{* * *}$ & $-0.233^{* * *}$ & $-0.134 * *$ \\
\hline Function Failure & $-0.235^{* * *}$ & $-0.147 * *$ & $0.104 *$ & -0.042 & $-0.280^{* * *}$ \\
\hline System Failure & $-0.206^{* * *}$ & $-0.161^{* * *}$ & $-0.296^{* * *}$ & $-0.313^{* * *}$ & $-0.243^{* * *}$ \\
\hline
\end{tabular}


Figure 1: Research Model

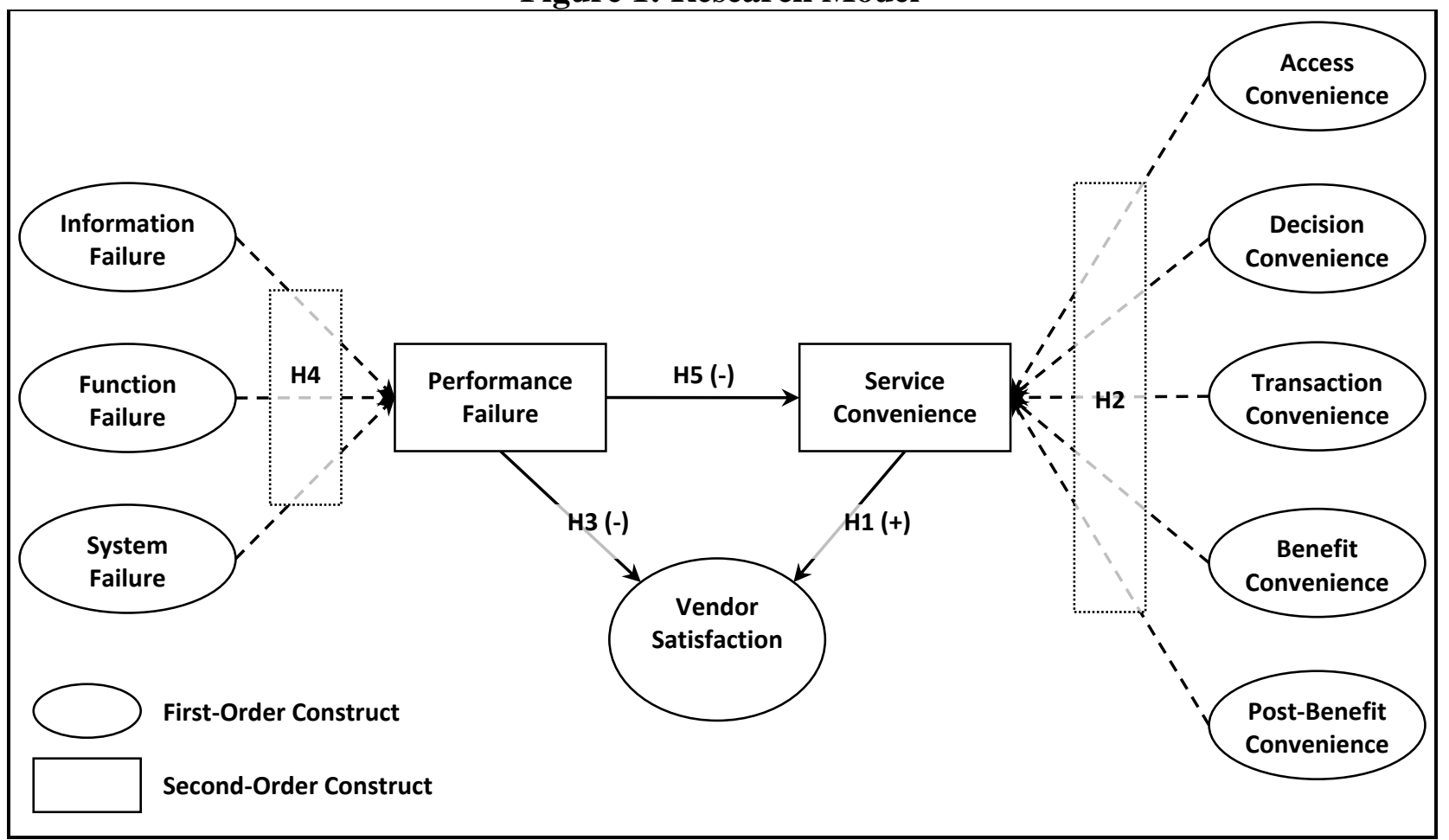


Figure 2: Results of Structural Model Analysis (Sample $N=227$ )

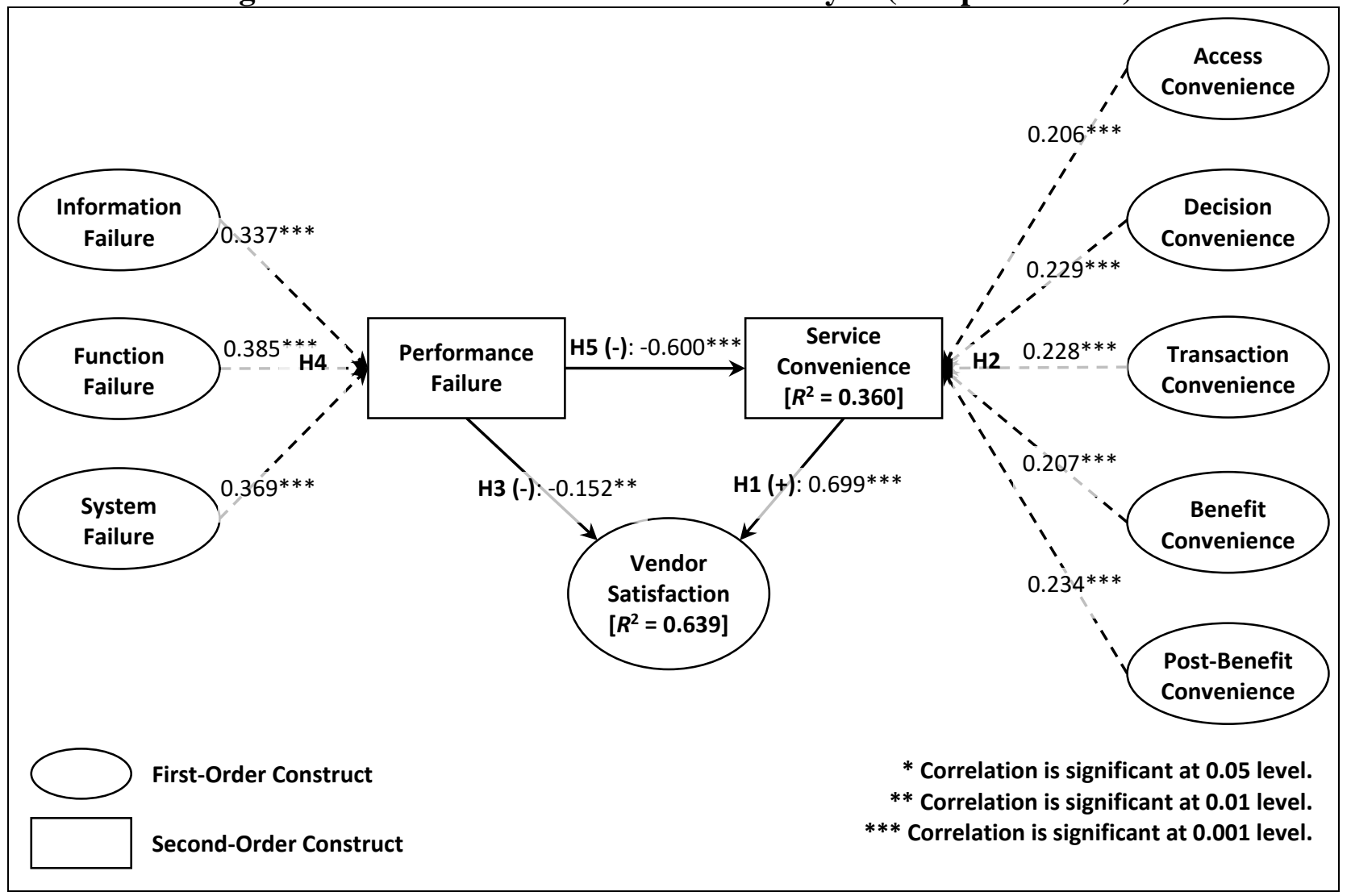


Figure 3: Results of Post-hoc Analysis (Sample $N=227$ )

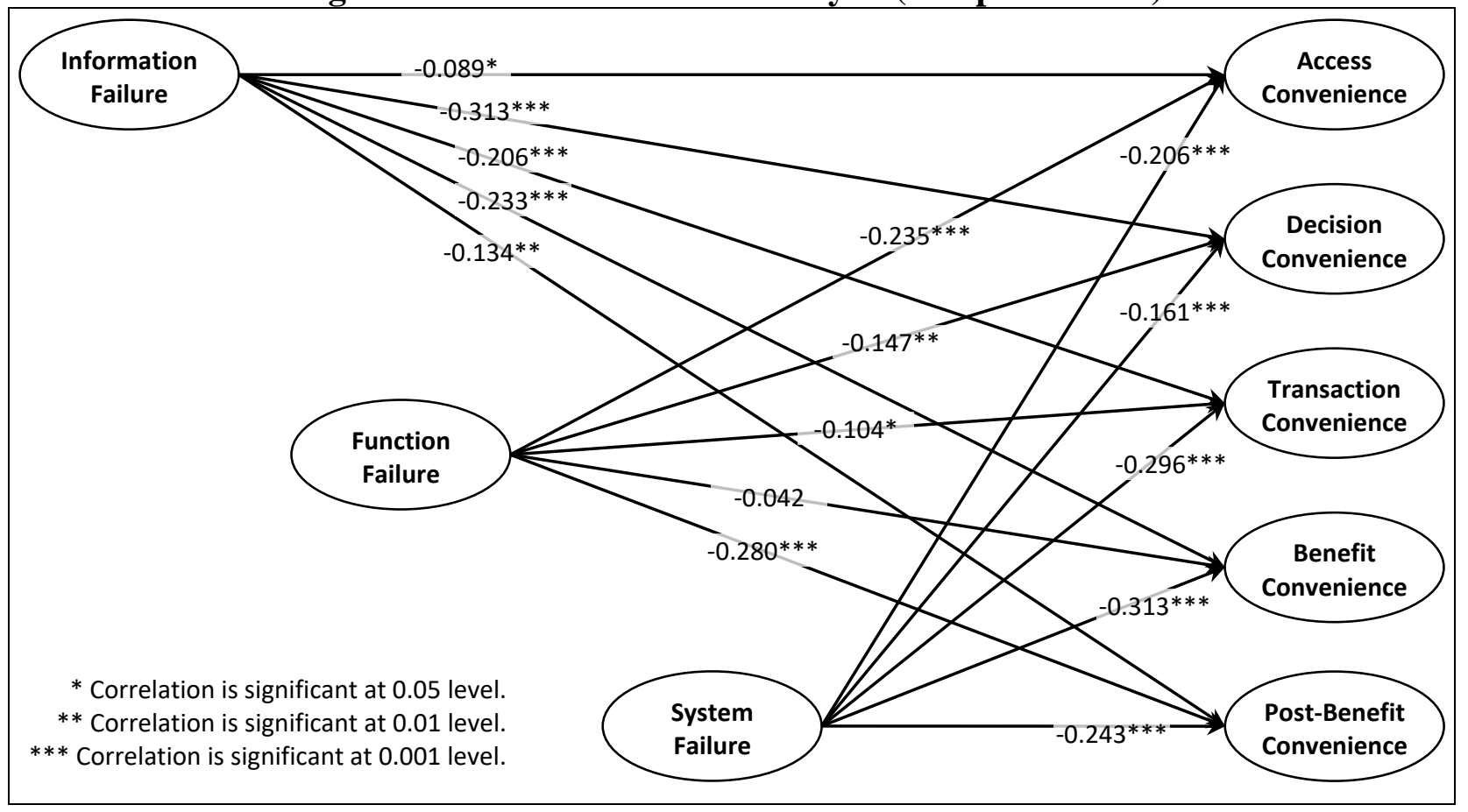

